\title{
ASSESSING THE KNOWLEDGE OF CERVICAL CANCER BY WOMEN FROM BIAŁA PODLASKA, LUBELSKIE VOIVODESHIP
}

\section{OCENA WIEDZY KOBIET ZAMIESZKAŁYCH W POWIECIE BIALSKIM, WOJEWÓDZTWO LUBELSKIE, DOTYCZĄCA RAKA SZYJKI MACICY}

\author{
Iwona Gładysz ${ }^{1(\mathrm{~A}, \mathrm{~B}, \mathrm{C}, \mathrm{D}, \mathrm{E}, \mathrm{F}, \mathrm{G})}$ \\ ${ }^{1}$ Department of Nursing, Pope John Paul II State School of Higher Education in Biała Podlaska, Poland
}

Authors' contribution Wkład autorów: A. Study design/planning zaplanowanie badań B. Data collection/entry zebranie danych C. Data analysis/statistics dane - analiza i statystyki D. Data interpretation interpretacja danych E. Preparation of manuscript przygotowanie artykułu F. Literature analysis/search wyszukiwanie i analiza literatury G. Funds collection zebranie funduszy
Tables: 3

Figures: 0

References: 14

Submitted: 2020 Nov 17

Accepted: 2020 Dec 9

\section{Summary}

Background. In the female population, cervical cancer is classified as one of the too late diagnosed cancers. Cervical cancer incidence and mortality rates in Poland are among the highest in the European Union. The aim of the paper is the assessment of women's knowledge about cervical cancer based on the study of the feminine population in the county of Biała Podlaska.

Material and methods. The study covered a group of 172 women living in the county of Biała Podlaska, Lubelskie Voivodeship, Poland. The research tool was an original questionnaire. The statistical analysis was performed using the STATISTICA v 10. program and the Pearson Chisquare test.

Results. More than half of respondents (55.8\%) indicated the following risk factors of cervical cancer: early onset of sexual life, many partners in a partner, infection of the cervix with HPV and herpes viruses, many deliveries, and smoking. The majority of respondents (62.2\%) believe that cytology and gynecological examination are part of the preventive examination.

Conclusions. 1. Respondents' knowledge about the risk factors of cervical cancer is sufficient. 2. Respondents above 26 years of age possess knowledge about human papillomavirus (HPV) vaccination as a means of preventing cervical cancer. 3. Young women's knowledge about HPV vaccination is insufficient.

Keywords: cervical cancer, knowledge, women

\section{Streszczenie}

Wprowadzenie. W populacji kobiet rak szyjki macicy zaliczany jest do nowotworów zbyt późno diagnozowanych. Wskaźniki zachorowalności oraz umieralności na raka szyjki macicy w Polsce należą do jednych z najwyższych w Unii Europejskiej. Celem pracy jest ocena wiedzy kobiet na temat profilaktyki raka szyjki macicy w oparciu o badania populacji kobiet zamieszkałych na terenie powiatu bialskiego.

Materiał i metody. Badaniami objęto grupę 172 kobiet zamieszkałych na terenie powiatu bialskiego, województwolubelskie, Polska. Narzędziem badawczym byłautorskikwestionariusz ankiety. Analizę statystyczną wykonano w programie STATISTICA v 10. z wykorzystaniem testu Chi kwadrat Pearsona.

Wyniki. Ponad połowa ankietowanych $(55,8 \%)$ jako czynniki zwiększające ryzyko rozwoju raka szyjki macicy wskazała: wczesne rozpoczęcie życia płciowego, dużą liczbę partnerów lub partnerek u partnera, zakażenia szyjki macicy wirusem HPV i wirusem opryszczki, dużą liczbę porodów, palenie papierosów. Większość respondentek $(62,2 \%)$ uważa, że cytologia i badanie ginekologiczne wchodzą w skład badań profilaktycznych.

Wnioski. 1. Wiedza respondentek na temat czynników mających wpływ na rozwój raka szyjki macicy jest wystarczająca. 2. Respondentki w grupie wiekowej powyżej 26 lat posiadają wiedzę dotyczącą szczepień przeciwko HPV w prewencji raka szyjki macicy. 3. Wiedza kobiet młodych, dotycząca szczepień przeciwko HPV jest nie wystarczająca.

Słowa kluczowe: rak szyjki macicy, wiedza, kobiety 


\section{Introduction}

Cancer is one of the most common diseases of the 21st century, apart from cardiovascular diseases, obesity and diabetes, accidents and trauma, and mental disorders [1]. In the female population, cervical cancer is classified as one of the too late diagnosed cancers. High incidence and mortality from cervical cancer, especially in young women, has been a serious problem for many years, not only in Poland but also in the world. Cervical cancer incidence and mortality rates in Poland are among the highest in the European Union [2]. According to the National Cancer Registry data, in 2017, its incidence rate was 6\%, and its mortality rate was $10 \%$ in the 20 44 age group [3].

Chronic HPV (Human Papillomavirus) infection is responsible for $90 \%$ of all cases. HPV infections in the countries with a high incidence of cervical cancer are in the range of 10-20\%, and in the countries with its low incidence, these are 5-10\% [4]. HPV infection is the main risk factor for cervical cancer. The main oncogenic type of the virus is HPV 16 (detected in 53\% of cancer and epithelial neoplasia cases - CIN1-CIN3) [5]. The second oncogenic type is type 18 (detected in 15\% of all cases). The likely factors include early onset of sexual life, many sexual partners, many ( $>5$ ) deliveries, smoking, low socioeconomic status, cervical dysplasia, use of oral hormonal contraception, diet poor in vitamin C, certain infections of the reproductive organ (chlamydiosis, gonorrhea, herpes virus, cytomegalovirus), and family history of cancer [6].

Cervical cancer is asymptomatic in the early stage, which is why screening tests are so important in its prevention [7]. Cancer prevention poses an important health problem in the health care system. Midwife's activities of preventing neoplastic diseases, including cervical cancer, should be manifested in shaping women's correct attitude towards the preventive examination.

The aim of the paper is to assess women's knowledge about cervical cancer based on a sample female population in the regions of Biała Podlaska, Poland.

\section{Material and methods}

The surveyed women varied in terms of age, education, place of residence, and occupation. Detailed results are presented in Table 1 . The study covered a group of 172 women living in the county of Biała Podlaska (the city of Biała Podlaska, as well as towns and rural areas in the county). The largest group were women aged 36-45 years (15.6\%) and above 55 years (14.5\%). The smallest group were women aged 18-25 years (6.8\%). $40.7 \%$ had higher education. The vast majority of respondents were from the countryside (48.8\%). The most numerous groups of women covered by the study were teachers (15.1\%) and nurses (11\%). The study group covered randomly selected patients of two physiotherapy offices, as well as university students and employees, in the county of Biała Podlaska. The research was conducted in the period from January to December 2017.

Table 1. Characteristics of the study group

\begin{tabular}{|c|c|c|c|}
\hline \multicolumn{2}{|c|}{ Study group } & $\mathrm{N}=172$ & $\%$ \\
\hline \multirow{5}{*}{ Age } & $18-25$ years & 24 & 6.8 \\
\hline & 26-35 years & 27 & 7.7 \\
\hline & $36-45$ years & 55 & 15.6 \\
\hline & $46-55$ years & 41 & 11.6 \\
\hline & Above 55 years & 25 & 14.5 \\
\hline \multirow{4}{*}{ Education } & Elementary & 19 & 11.0 \\
\hline & Vocational & 27 & 15.7 \\
\hline & Secondary & 56 & 32.6 \\
\hline & Higher & 70 & 40.7 \\
\hline \multirow{3}{*}{$\begin{array}{c}\text { Place of residence in } \\
\text { the county of Biała } \\
\text { Podlaska }\end{array}$} & Countryside & 84 & 48.8 \\
\hline & City below 50,000 residents & 54 & 31.4 \\
\hline & The city of Biała Podlaska & 34 & 19.8 \\
\hline
\end{tabular}

The research tool was an original questionnaire on women's knowledge about cervical cancer, consisting of 26 questions. Detailed results are presented in Table 1. The obtained results were subject to a statistical analysis performed using the STATISTICA v 10. Program and the Pearson Chi-square test. The level of significance was $\mathrm{p} \leq 0.05$. 


\section{Results}

Data are presented in the tables. More than half of respondents, 55.8\% (96), indicated the following risk factors of cervical cancer: early onset of sexual life, many partners in a partner, infection of the cervix with HPV and herpes virus, many deliveries, and smoking. A group of 5.8\% (10) of respondents lacked knowledge about the risk factors of cervical cancer.

As for the possible symptoms of cervical cancer, 47.1\% (81) of respondents indicated: spotting or contact bleeding from the genital tract, for example, related to sexual intercourse, other spotting or bleeding from the genital tract unrelated to the cycle, and change in nature (appearance, smell) of the vagina discharge. 9.9\% (17) of respondents lacked knowledge about the possible symptoms of cervical cancer. Concerning the symptoms of HPV infection, 29.1\% (50) of respondents indicated vaginal spotting, 25\% (43) of them indicated vaginal discharge, $19.8 \%$ (34) of them indicated genital warts, and 26.2\% (45) of respondents lacked knowledge about the symptoms of HPV infection.

In the study group, the most common reasons for having a pap smear were: vaginal discharge - for 43.1\% (66) of respondents, spotting from the genital tract after intercourse - for 34\% (52) of them, and cervical cancer in members of the closest family - for $22.9 \%$ (35) of them. Detailed results are presented in Table 2.

Table 2. Respondents' knowledge about the symptoms and risk factors of cervical cancer

\begin{tabular}{|c|c|c|c|}
\hline & & $\mathrm{N}=172$ & $\%$ \\
\hline \multirow{7}{*}{$\begin{array}{l}\text { Which of the } \\
\text { following factors } \\
\text { increases the risk of } \\
\text { developing cervical } \\
\text { cancer, in your } \\
\text { opinion? }\end{array}$} & early onset of sexual life & 9 & 5.2 \\
\hline & many sexual partners in a partner & 14 & 8.1 \\
\hline & $\begin{array}{c}\text { cervix infection with human papillomaviruses } \\
\text { or herpes virus }\end{array}$ & 20 & 11.6 \\
\hline & many deliveries at a young age & 16 & 9.3 \\
\hline & smoking & 7 & 4.1 \\
\hline & all of the above & 96 & 55.8 \\
\hline & I do not know & 10 & 5.8 \\
\hline \multirow{5}{*}{$\begin{array}{l}\text { Which of the } \\
\text { following symptoms } \\
\text { may be a sign of } \\
\text { cervical cancer, in } \\
\text { your opinion? }\end{array}$} & $\begin{array}{l}\text { vaginal spotting or contact bleeding, for example, } \\
\text { related to sexual intercourse }\end{array}$ & 23 & 13.4 \\
\hline & $\begin{array}{l}\text { other spotting or bleeding from the genital tract, } \\
\text { unrelated to the cycle }\end{array}$ & 29 & 16.9 \\
\hline & change in nature (appearance, smell) of vaginal discharge & 22 & 12.8 \\
\hline & all of the above & 81 & 47.1 \\
\hline & I do not know & 17 & 9.9 \\
\hline \multirow{4}{*}{$\begin{array}{l}\text { What are the } \\
\text { symptoms of } \\
\text { HPV (Human } \\
\text { Papillomavirus) } \\
\text { infection? }\end{array}$} & anogenital wart & 34 & 19.8 \\
\hline & vaginal discharge & 43 & 25.0 \\
\hline & spotting from the genital tract & 50 & 29.1 \\
\hline & I do not know & 45 & 26.2 \\
\hline \multirow{3}{*}{$\begin{array}{l}\text { The reason for having } \\
\text { a pap smear was: }\end{array}$} & $\begin{array}{l}\text { the occurrence of cervical cancer in members } \\
\text { of the closest family }\end{array}$ & 35 & 22.9 \\
\hline & spotting from the genital tract after intercourse & 52 & 34.0 \\
\hline & vaginal discharge & 66 & 43.1 \\
\hline
\end{tabular}

In the 18-25 age group, the majority of respondents, $70.8 \%$ (17), correctly indicated the risk factors of cervical cancer. More than half of respondents, 51.2\% (21), in the 46-55 age group, and almost half of respondents in the remaining age groups knew possible symptoms of cervical cancer. In the 36-45 age group, 23.6\% (13) of respondents know the symptoms of HPV infection. The reasons for having a pap smear in all age groups were vaginal discharge and spotting from the genital tract after intercourse, and in the 36-45 age group, as many as $39.1 \%$ (21) of respondents indicated cervical cancer in members of the closest family.

An objective assessment to the responses to determine women's knowledge about the prevention of cervical cancer. More than half of the respondents, 66.9\% (115), replied that woman should visit a gynecologist for the first time at the age of 15-20. The majority of respondents, 63.4\% (109), first visited a gynecologist at the age of 18-25. When asked about the last visit to a gynecologist, 38.4\% (66) of respondents declared having made it in the last year, $22.1 \%$ (38) of them in the last 2 years, $17.4 \%$ (30) of them in the last 3 years, $18 \%$ (31) of them made it $4-5$ years ago, and no visits were declared by $4.1 \%$ (7).

The majority of respondents, $62.2 \%$ (107), believe that cytology and gynecological examination are part of the preventive examination. More than half of respondents, 56.4\% (97), believe that Populacyjny program 
profilaktyki i wczesnego wykrywania raka szyjki macicy (Population Program for the Prevention and Early Detection of Cervical Cancer) applies to all women, and $25.6 \%$ (44) of respondents believe that it applies to women aged 25-59 who did not undergo cytology in the last 3 years.

A pap smear performed in the last year was declared by $28.5 \%$ (49) of respondents, and a pap smear performed in the last 1-2 years was declared by 25\% (43) of them. Almost half of the respondents, 43.6\% (75), indicated that adult women should visit a gynecologist for a checkup once a year to detect cervical cancer, $28.5 \%$ (49) indicated that an adult woman should do it every 2-3 years. When asked at what age a woman should be vaccinated against HPV, 43.6\% (75) of respondents answered that it should be done before starting sexual life, and 29.1\% (50) lacked knowledge about the age qualifying for HPV vaccination. More than half of respondents, $54.1 \%$ (93), believe that HPV vaccination partially protects against cervical cancer, and 56.4\% (97) believe that HPV vaccination does not entitle women to stop performing control cytology. Detailed results are presented in Table 3.

Table 3. Respondents' knowledge about the methods of cervical cancer prevention

\begin{tabular}{|c|c|c|c|}
\hline & & $\mathrm{N}=172$ & $\%$ \\
\hline \multirow{3}{*}{$\begin{array}{l}\text { At what age should } \\
\text { a woman visit } \\
\text { a gynecologist for the } \\
\text { first time? }\end{array}$} & $15-20$ & 115 & 66.9 \\
\hline & $21-25$ & 51 & 29.7 \\
\hline & $26-31$ & 6 & 3.5 \\
\hline \multirow{5}{*}{$\begin{array}{l}\text { How old were you } \\
\text { at your first visit to } \\
\text { a gynecologist? }\end{array}$} & $18-25$ & 109 & 63.4 \\
\hline & $26-35$ & 39 & 22.7 \\
\hline & $36-45$ & 8 & 4.7 \\
\hline & $46-55$ & 14 & 8.1 \\
\hline & above 56 & 2 & 1.2 \\
\hline \multirow{5}{*}{$\begin{array}{l}\text { When was your } \\
\text { last visit to } \\
\text { a gynecologist? }\end{array}$} & in the last year & 66 & 38.4 \\
\hline & in the last 2 years & 38 & 22.1 \\
\hline & in the last 3 years & 30 & 17.4 \\
\hline & 4-5 years ago & 31 & 18.0 \\
\hline & never & 7 & 4.1 \\
\hline \multirow{4}{*}{$\begin{array}{c}\text { What is part of } \\
\text { a preventive } \\
\text { examination, in your } \\
\text { opinion? }\end{array}$} & cytology & 36 & 20.9 \\
\hline & gynecological examination & 19 & 11.0 \\
\hline & all of the above & 107 & 62.2 \\
\hline & I do not know & 10 & 5.8 \\
\hline \multirow{3}{*}{$\begin{array}{l}\text { Who does Population } \\
\text { Program for the } \\
\text { Prevention and Early } \\
\text { Detection of Cervical } \\
\text { Cancer apply to? }\end{array}$} & $\begin{array}{l}\text { women aged 25-59 who have not had a pap smear in the last } \\
3 \text { years }\end{array}$ & 44 & 25.6 \\
\hline & $\begin{array}{l}\text { women aged 25-59 with risk factors (infected with HIV, } \\
\text { taking immunosuppressants, infected with HPV) }\end{array}$ & 31 & 18.0 \\
\hline & all women & 97 & 56.4 \\
\hline \multirow{6}{*}{$\begin{array}{l}\text { When did you have } \\
\text { the last pap smear? }\end{array}$} & within the past 12 months & 49 & 28.5 \\
\hline & in the last $1-2$ years & 43 & 25.0 \\
\hline & in the last 2-3 years & 33 & 19.2 \\
\hline & in the last 3-4 years & 28 & 16.3 \\
\hline & never & 12 & 7.0 \\
\hline & I do not remember & 7 & 4.1 \\
\hline \multirow{5}{*}{$\begin{array}{l}\text { How often should } \\
\text { an adult woman } \\
\text { visit a gynecologist } \\
\text { for cervical cancer } \\
\text { screening, in your } \\
\text { opinion? }\end{array}$} & 6-monthly & 23 & 13.4 \\
\hline & once a year & 75 & 43.6 \\
\hline & every $2-3$ years & 49 & 28.5 \\
\hline & every $4-5$ years & 16 & 9.3 \\
\hline & I do not know & 9 & 5.2 \\
\hline \multirow{4}{*}{$\begin{array}{l}\text { At what age should } \\
\text { HPV vaccination be } \\
\text { done? }\end{array}$} & before starting sexual life & 75 & 43.6 \\
\hline & after the age of 18 & 29 & 16.9 \\
\hline & after the first menstruation & 18 & 10.5 \\
\hline & I do not know & 50 & 29.1 \\
\hline
\end{tabular}




\begin{tabular}{|c|c|c|c|}
\hline \multirow{2}{*}{$\begin{array}{c}\text { Do you think that } \\
\text { the HPV (Human } \\
\text { Papillomavirus) }\end{array}$} & completely (in 100\%) & 29 & 16.9 \\
\cline { 2 - 4 } $\begin{array}{c}\text { vaccine protects } \\
\text { against cervical } \\
\text { cancer? }\end{array}$ & partially & 93 & 54.1 \\
\cline { 2 - 4 } & not at all & 10 & 5.8 \\
\hline \multirow{2}{\text{Doyouthink}}{$\begin{array}{c}\text { HPV (Human } \\
\text { Papillomavirus) } \\
\text { vaccination: }\end{array}$} & I do not know & relieves from performing control cytological tests & 23.3 \\
\cline { 2 - 4 } & relieves from pap smear tests for the duration of the \\
vaccine's action & 9 & 5.2 \\
\cline { 2 - 4 } & I do not know & 97 & 56.4 \\
\hline
\end{tabular}

Taking an age to account when analyzing respondents' knowledge about cervical cancer prevention methods, most respondents from the 26-35 age group, 77.8\% (21), indicated that a woman should visit a gynecologist for the first time at the age of 15-20 years. The age of 18-25 years was indicated by as many as $79.2 \%$ (19) of the respondents from the same age group. The highest percentage of the respondents in the 18-25 age group, 66.7\% (16), visited a gynecologist in the last year. The analyzed group was characterized by a statistical significance $(p=0.0018) .70 .8 \%$ (17) of the respondents from the 18-25 age group indicated cytology and gynecological examination as elements of the preventive examination. The analyzed group was characterized by a statistical significance ( $\mathrm{p}=0.0386)$. Most respondents above 55 years of age, 68\% (17), indicated that Populacyjny program profilaktyki i wczesnego wykrywania raka szyjki macicy (Population Program for the Prevention and Early Detection of Cervical Cancer) applies to all women.

In the last year, a pap smear was performed by the majority of women in the 36-45 age group (41.8\%). The analyzed group was characterized by a statistical significance $(p=0.0286)$. According to almost $48 \%$ (12) of the respondents above 55 years of age, an adult woman should have a pap smear once a year. More than half of the respondents from the 36-45 age group, 50.9\% (28), believe that HPV vaccination should be done before starting sexual life, and 59.3\% (32) from the 26-35 age group believe that the HPV vaccine does not completely protect against cervical cancer, while 60\% (16) of the respondents from the 36-45 age group believe that HPV vaccination does not entitle women to stop performing the control cytology.

\section{Discussion}

One of the factors influencing both the incidence and development of cervical cancer is the knowledge about this type of cancer and about the possibilities of its prevention. Another study, conducted in the Wielkopolskie Voivodeship on a group of 297 women, thus similar to the group analyzed in this study, shows that almost $2 / 3$ of respondents, $65.3 \%$ (194), knew methods of genital cancer prevention and were convinced of the influence of healthy lifestyle on cancer prevention [8].

The studies by Baran, Kornacka and Szela, conducted on a group of 120 respondents, showed that as many as $43 \%$ of respondents lacked knowledge about the risk factors of cervical cancer. However, common research shows a much lower percentage of women who do not know these factors [9]. Olejniczak and Bień obtained similar positive results in a study on students of medical and non-medical faculties at Medical University of Warsaw and Kielce University of Technology. The results obtained by the authors show that the knowledge of female medical students regarding the symptoms and risk factors of cervical cancer does not differ from the knowledge of female students of non-medical faculties [10].

Our study showed a high (30\%) percentage of women lacking knowledge about the symptoms of HPV infection. The study results by Durka and Stefanek show that $87.9 \%$ of respondents indicated infection with HPV as the cause of the development of cervical cancer [11]. Interesting study results were presented by the authors examining a group of 88 girls from the first, second, and third grades of secondary school, living both in the countryside and in the city. The study results show that $29 \%$ of the inhabitants of urban areas and $28 \%$ of the inhabitants of rural areas report skin contact in the genital area as the main route of HPV infection. The results of our study of a similar age group that is young women show that as many as $70.8 \%$ of women in the $18-25$ age group know the risk factors of cervical cancer [12].

The next group of questions concerned the importance of cervical cancer prevention. Taking to account the age of the surveyed women, in the last year, a pap smear was performed by the majority of women in the 18-25 age group (37.5\%) i.e., that is by young women. According to almost $48 \%$ of the respondents above 56 years of age, an adult woman should have a pap smear once a year. The study by Pancewicz et al. conducted on a group of 100 women and 100 men shows that the best-known programs for cervical cancer prevention were cytology 
( $80 \%$ of women, $42 \%$ of men) and vaccination ( $66 \%$ of women, $26 \%$ of men), and $44 \%$ of women and $38 \%$ of men believed that a pap smear should be performed once a year [13]. The study also shows that the majority of female respondents (62.2\%) believe that cytology and gynecological examination are part of the preventive examination. The same study by Pancewicz et al. shows that $46 \%$ of respondents received an invitation to a pap smear, but as many as $67 \%$ of them did not use it [13]. The study results also show that more than half of respondents know the proper time of starting HPV vaccination. Completely different results were obtained in the study on middle school students, presented by Strama et al., indicating that more than half of the girls (53\%) do not know the effects of HPV vaccines, and 34\% believe that they reduce the risk of cervical cancer and other changes caused by HPV, but do not eliminate them [14].

\section{Conclusions}

1. Respondents' knowledge about the risk factors of cervical cancer is sufficient.

2. Respondents above 26 years of age possess knowledge about HPV vaccination as a means of preventing cervical cancer.

3. Young women's knowledge about HPV vaccination is insufficient.

\section{References:}

1. Arbyn M, Weiderpass E, Bruni L, Sanjosé S, Saraiya M, Ferlay J, et al. Estimates of incidence and mortality of cervical cancer in 2018: a worldwide analysis. Lancet Glob Health. 2020; 8(2): $191-203$. https://doi.org/10.1016/S2214-109X(19)30482-6

2. Wiszniewska M, Magnuska J, Lipińska-Ojrzanowska A, Pepłońska B, Hanke W, Kalinka J, etal. [The prophylactic operational model integrated with occupational healthcare - prophylactic of some types of cancers among women]. Medycyna Pracy. 2018; 69(4): 439-455 (in Polish). https://doi.org/10.13075/mp.5893.00665

3. Didkowska J, Wojciechowska U. [Malignant cancer incidents and mortality in Poland] [Internet]. Warszawa: Krajowy Rejestr Nowotworów, Narodowy Instytut Onkologii im. Marii Skłodowskiej-Curie - Państwowy Instytut Badawczy [cited 2020 May 9]. Available from: http://onkologia.org.pl/raporty/ (in Polish).

4. HPV Information Centre. Human papillomavirus and related diseases report [Internet]. Barcelona: ICO Information Centre on HPV and Cancer; 2019 [cited 2020 May 9]. Available from: http://www.hpvcentre.net

5. Korfantel J, Mądry R. [Neoplasms of the female reproductive system] [Internet]. Warszawa: Polskie Towarzystwo Onkologii Klinicznej; 2019 [cited 2020 May 9]. Available from: http://onkologia.zalecenia. med.pl/pdf/PTOK_2013_06_Nowotwory (in Polish).

6. Swift BE, Wang L, Jembere N, Kupets R. Risk of recurrence after treatment for cervical intraepithelial neoplasia 3 and adenocarcinoma in situ of the cervix: recurrence of CIN 3 and AIS of Cervix. J Low Genit Tract Dis. 2020; 24(3): 252-258. https://doi.org/10.1097/LGT.0000000000000542

7. Kitajewska W, Szeląg W, Kopański Z. [Civilisation diseases and prevention]. Journal of Clinical Healthcare. 2014; 1: 3-7 (in Polish).

8. Stanisławska J, Janikowska K, Stachowska M, Talarska D, Drozd-Gajdus E, Szewczyczak M. [Assessment of women's knowledge on prevention of breast cancer and cervical cancer]. Probl Hig Epidemiol. 2016; 97(1): 38-44 (in Polish).

9. Baran W, Kornacka K, Szela S. [Assessment of the knowledge of women from Podkarpacka regarding cervical cancer prevention]. Przegląd Medyczny Uniwersytetu Rzeszowskiego i Narodowego Instytutu Leków w Warszawie Rzeszów. 2013; 3: 311-331 (in Polish).

10. Olejniczak D, Bień M. [The attitude of the female students of medical and non-medical fields of studies towards the cervical cancer prophylaxis]. Studia Medyczne. 2014; 30(3): 162-172 (in Polish). https://doi.org/10.5114/ms.2014.45421

11. Stefanek A, Durka P. [Women's knowledge of prevention of cervical cancer]. Polski Przegląd Nauk o Zdrowiu. 2014; 38(1): 29-38 (in Polish).

12. Sawaryn D, Wróbel A. [Young girls' knowledge level concerning cervical cancer]. Borgis - Medycyna Rodzinna. 2011; 2: 35-42 (in Polish).

13. Pacewicz M, Krajewska-Kułak E, Krajewska-Ferishah K. [Prophylaxis of cervical cancer in women and men perception]. Medycyna Paliatywna. 2012; 4(4): 217-228 (in Polish).

14. Strama A, Michalak A, Szostkowska M. [Middle school girls' knowledge of preventative measures against cervical cancer]. Zdrowie i Dobrostan. 2015: 1: 9-16 (in Polish). 